\title{
"As cores da servidão" e outros poemas
}

\section{As cores da servidão: variações}

1.

Entrou no avião para a primeira fila, e era loura, mala de mão macia em boa pele

À sua frente, e jovem como

ela, o marido elegante e confortável na cor da sua íris internacional

Atrás dos dois, na fila de embarcar, e era quase menina, uma criada, touca branca e bordada e uma criança aconchegada ao peito

Eram, em provisório, senhores dela, os donos do seu tempo e vida, gestos sagazes como linces jactantes de poder

E negra, ela, sem caminhar suave de gazela, sentou-se com o filho que era deles na fila mais ao fundo do longo corredor 
REDE INTERNACIONAL LYRACOMPOETICS

Ana Luísa Amaral

2.

vestida de criada, não era

carnaval, era real, a touca

e farda de moderna escrava

dos seus donos, embora

transitórios, olhos de lança

fitando uma gazela, olhar

que haviam de passar

ao filho, descansando pesado

de encontro ao corpo dela 


\section{história politicamente incorrecta para quem é mais pequenino}

Se eu calçasse o 33

era muito boazinha

falaria aos passarinhos

ia ao baile disfarçada

de princesa

E conhecia os pais dele e dançaria com ele até quase à meia noite convencida de que aquilo era o amor

Se eu calçasse o 33 perderia o sapatinho e ficaria sem fôlego de correr desaustinada ao longo da escadaria. Que maçada!

Se eu calçasse o 33 tinha uma madrinha-fada a dar-me longo vestido lantejoula de casada e servia-me o sapato de cristal Mas eu calço o 39 e quem se casou foi ela a do pezinho pequeno e olho de Cinderela

Sorte a dela!

Que a Anastácia e a Griselda ficaram ali sozinhas sem passarinhos, só ratos e dois gatos que não sabem transformar-se em carruagem 
E eu sozinha aqui fiquei cometendo arte menor, a de transformar palavras no que soa ser amor mas só soa ser amor

Que sorte, a de Cinderela! Sorte a dela?

É que (diz a outra história, a feminista)

na noite do casamento, já depois das badaladas entre despir o vestido e descalçar sapatinho de cristal

o príncipe transformou-se em rã verde e trapezista e de veneno mortal e desatou a morderIhe o dedo grande do pé

De bem pouco lhe serviu, a Cinderela, pezinho de 33 - 


\section{Genealogias, impressões e voos}

Era de Angola e negra a minha trisavó, encontrei outro dia o seu nome no verso não de poema disperso por gaveta, mas de papel impressionado a luz e a cristais de prata

Foi o seu filho quem lhe escreveu o nome na fotografia, em gesto de memória. Lembro-me dele ainda, vagamente, eu muito menina e ele quase cego, tocava violoncelo, esse meu bisavô, falava devagar e num ritmo incerto e delicado

Estão desbotados ambos por idades, fotografia e a minha trisavó:

o seu cabelo branco em caracóis (ínfimos olhos de ave tropical), uma pele muito lisa que lhe invejo, eu que lhe herdei o nome, mas não a macieza e cor de pele

Podia a minha filha revelar pigmentos transmitidos por essa mulher doce, como dizia ainda a minha avó, mas os olhos azuis da minha filha vieram-lhe de novas impressões

O pigmento lançado pelo tempo de ADN comum chegou à minha filha em camada invisível: num figmento de pele imperceptível, uma herança de voz: música de korá mais do que violoncelo em ritmo europeu 
REDE INTERNACIONAL LYRACOMPOETICS

Ana Luísa Amaral

Não se extinguem de facto os vulcões, antes hão-de abrigar, em comoção de luz, reimpressões de nós tingidas pela música de eternos filamentos: pássaros que algum dia, a cópia nunca igual, mas de tal gloriosa imperfeição que o voo lhes é asa - 


\section{Dois cavalos: paisagem}

Estão lado a lado, naquela praça em frente da igreja, nesse calor de quando o mundo oscila na linha de horizonte, e o rio quase defronte: uma miragem

Estão lado a lado, sujos de pó, as cabeças tombadas para a frente, unidos pelo jugo desigual, a carroça apoiada no muro mas pronta a ser unida aos corpos deles

Estarão feitos assim: velhos amigos, os corpos encostados mesmo neste calor, pela aliança muda?

Arreios, cabeçadas, todos os instrumentos do que parece ser mansa tortura mais o freio, ou bridão, parecido com aquele colocado na boca das mulheres que desobedeciam,

e era isso há muito tempo, pelo menos quatro séculos, ou semelhante ao que se usava nos escravos, cobrindo-lhes a boca para que não se envenenassem, porque se recusavam a viver escravos e era isso quase agora, no século passado

Mas eles não criam caos nem desacato, não se revoltam nem tentam o veneno se o freio agudo lhes fere, pungente, gengiva, língua, osso

Só se encostam quietos, um ao outro, cabeças derrubadas para a frente, 


\author{
à espera do chicote \\ que chegará depois com a carroça, pronta \\ para a entrega das coisas \\ humanas, o comércio \\ E é esta a mais perfeita \\ das colonizações
}

NOTA

* Ana Luísa Amaral é autora de mais de três dezenas de livros, de poesia, teatro, ficção, infanto-juvenis e de ensaio, traduzidos e editados em inúmeros países. Traduziu poetas como Emily Dickinson, William Shakespeare ou Louise Glück. Obteve várias distinções e prémios em Portugal e no estrangeiro, como o Prémio Literário Correntes d'Escritas, o Premio de Poesía Fondazione Roma, o Grande Prémio de Poesia da APE, o Premio PEN de Narrativa, o Prémio Leteo, ou o Prémio Vergílio Ferreira. Tem, com Luís Caetano, um programa de rádio semanal na Antena2 sobre poesia, O som que os versos fazem ao abrir. É professora aposentada da Universidade do Porto e membro do Instituto de Literatura Comparada Margarida Losa, onde coordenou vários projectos internacionais e linhas de investigação. 